\title{
The influence of gas cookers on the concentration of hazardous substances in individual kitchens and in living rooms, including ventilation for the final air quality
}

\author{
Alexander Shkarovskiy ${ }^{1, *}$, and Agnieszka Maliszewska ${ }^{1}$ \\ ${ }^{1}$ Technical University of Koszalin, Faculty of Civil Engineering, Environmental and \\ Geodetic Sciences, al. Śniadeckich 2, PL-75-453 Koszalin, Poland
}

\begin{abstract}
In the near future, the development of gas infrastructure and the elimination of the "white spots" on the gas map of Poland will become a reality. Currently in Poland, the most popular is using cookers powered with natural gas (about 56\%). Liquid gas is less popular - the number of households is estimated at about $14 \%$. The wider availability of gas will certainly contribute to the increase in the number of gas cookers. We spend a large part of our lives in apartments, not realizing that we are directly exposed to toxic substances from the combustion of organic fuel. These substances are not inert to humans and even their relatively low concentrations can influence on health. The authors of the article try to research the evidences of damaging effects of toxic components from gas stoves, taking into consideration the impact of ventilation on the final air quality in individual kitchens and living rooms.
\end{abstract}

\section{The hazardous substances}

During the combustion of gas in the gas stove burner, a lot of by-products are formed, which the most important of ones are nitrogen oxides (NOx) and carbon monoxide (CO).

Carbon monoxide is a gas which is highly poisonous, colorless and odorless. It is slightly lighter than air, it can easy mix with and spread the whole space of room. It forms when there is no complete combustion process, where the final products should be only $\mathrm{H}_{2} \mathrm{O}$ and $\mathrm{CO}_{2}$. The reason of it, can be for example insufficient amount of fresh air, which has to be supplied to the cooker, poor mixing the gas with air, contact between the flame and the cold surface or polluted, unchecked, not properly adjusted gas stove burner.

Nitrogen oxides are one of the most dangerous components that pollute the atmosphere. They are considered to be almost ten times more toxic than carbon monoxide $(\mathrm{CO})$, and several times from sulfur dioxide $\left(\mathrm{SO}_{2}\right)$. The most important of them are the nitrogen dioxide and oxide, which form due to the needing high temperature combustion processes with air access.

\footnotetext{
${ }^{1}$ Corresponding author: agnieszka.maliszewska@tu.koszalin.pl
} 
In Poland, the regulations [1] determine the permissible concentrations only for 35 harmful substances for the living spaces. Unfortunately, there are no detailed standards for the permissible concentration of nitric oxide, which may form even with the average using the gas cookers in concentrations that can be danger, according to numerous studies [2, 3], [4]. The standards for permissible concentrations of nitric oxide are included only in relation to the working environment [5].

There not a lot of literature containing data which present the consequences of longterm exposure (from several days to several months) in a room with low levels of carbon monoxide and nitrogen oxides. Although acute $\mathrm{CO}$ and NOx poisoning is usually well recognized, the symptoms of chronic exposure are often unrecognized or misdiagnosed because they are not clear.

In the Department of Forensic Medicine at the Jagiellonian University in Krakow [6] archival post-mortem examination reports were analyzed for a period of 50 years (from 1947 to 1996). The analysis was based on the results of blood tests from people, who died of carbon monoxide poisoning, assessing the content of carbon monoxide hemoglobin. In the analyzed period, there were 1396 cases of poisoning with carbon monoxide in a different age group (from several months to 98 years).

The largest number of victims was recorded in the autumn and winter period - from September to March there were $64 \%$ of all fatal poisonings. In the spring, $21.85 \%$ cases of deaths were found and $12.1 \%$ in the summer.

The analysis of the post-mortem examination shows that the most fatal poisonings with carbon monoxide occurred in flats $(69.48 \%$ of cases), of which up to $27 \%$ was the effect of using a gas stove:

Table 1. Percentage share of carbon monoxide poisoning depending on internal environment in the years 1947-1996.

\begin{tabular}{|c|c|c|}
\hline I. & $27.87 \%$ & gas leak from gas stove in the kitchen \\
\hline II, & $25.21 \%$ & gas leak from inefficient or badly used heating devices \\
\hline III. & $16.40 \%$ & gas leak from gas heater in bathrooms \\
\hline IV. & $14.83 \%$ & poisoning due to fire \\
\hline V. & $4.66 \%$ & In the boiler room, among the stokers \\
\hline VI. & $4.08 \%$ & In garaged cars (exhaust victims) \\
\hline VII. & $0.57 \%$ & Inside the car (gas leak from heating devices of liquid gas ) \\
\hline VIII. & $6.38 \%$ & $\begin{array}{c}\text { Other cases and those in which no data of the circumstances of death were } \\
\text { available }\end{array}$ \\
\hline
\end{tabular}

\section{Ventilation}

The standard [7] specifies the required ventilation for hygienic and sanitary purposes for living spaces, defined as the sum of air streams removed from rooms, irrespective of the type of ventilation:

Table 2. The minimum stream of ventilation air.

\begin{tabular}{|c|c|c|}
\hline O.N. & Kind of room & $\begin{array}{c}\text { The minimum stream of ventilation air, } \\
\mathbf{V}\left[\mathbf{m}^{\mathbf{3}} / \mathbf{h}\right]\end{array}$ \\
\hline 1 & $\begin{array}{c}\text { Kitchen with an outside window, equipped } \\
\text { with a gas or coal stove }\end{array}$ & 70 \\
\hline 2 & $\begin{array}{c}\text { Kitchen with an outside window, equipped } \\
\text { with an electric stove }\end{array}$ & 30 \\
\hline 3 & $\begin{array}{c}\text { Kitchen without an outside window or } \\
\text { kitchenette, equipped with an electric stove }\end{array}$ & 50 \\
\hline
\end{tabular}




\begin{tabular}{|c|c|c|}
\hline 4 & Apartment for 3 people & 30 \\
\hline 5 & $\begin{array}{c}\text { Kitchen without an outside window, } \\
\text { equipped with a gas or coal stoves }\end{array}$ & 70 (mechanical exhaust ventilation) \\
\hline 6 & Apartment for more than 3 people & 50 \\
\hline 7 & Bathroom & 50 \\
\hline 8 & Individual toleit & 30 \\
\hline 9 & Utility room without an outside window & 15 \\
\hline
\end{tabular}

Often the selection of gravity channels in accommodation spaces is neglected and ignored by design. Ventilation ducts for each flat should be individually calculated by the right selection of their cross-sections and number, for the reference design conditions, such as outdoor temperature $+12^{\circ} \mathrm{C}$, internal temperature $+20^{\circ} \mathrm{C}$, wind speed $=0 \mathrm{~m} / \mathrm{s}$, according to the standard [6].

Most often calculations are not made, and ventilation ducts are usually built in brick technology with a cross-section of $140 \times 140 \mathrm{~mm}$ or made of ceramic hollow blocks with a diameter of $150 \mathrm{~mm}$, without considering their height and location in the apartment.

The approximate size of the air streams extracted by the gravity duct built in brick technology for the reference design conditions, shown in the table below [8].

Table 3. Approximate values of the flow velocity and the amount of exhaust air streams in brick made ducts for the reference design conditions.

\begin{tabular}{|c|c|c|c|c|c|c|}
\hline \multirow{2}{*}{$\begin{array}{c}\text { High of the } \\
\text { stack } \\
\text { (ventilation } \\
\text { duct) }\end{array}$} & \multirow{2}{*}{$\begin{array}{c}\text { Air speed } \\
\text { at a temperature } \\
\text { differential of } \\
8^{\circ} \mathrm{C}\end{array}$} & \multicolumn{5}{|c|}{ Gravity ventilation duct build in brick technology } \\
\hline & & $\begin{array}{c}0.14 \times 0.1 \\
4 \mathrm{~m} \\
0.020 \mathrm{~m}^{3}\end{array}$ & $\begin{array}{c}0.14 \times 0.2 \\
0 \mathrm{~m} \\
0.028 \mathrm{~m}^{3}\end{array}$ & $\begin{array}{c}0.14 \times 0.27 \\
\text { m } \\
0.038 \text { m }^{3}\end{array}$ & $\begin{array}{c}0.20 \times 0.20 \\
m \\
0.040 \mathrm{~m}^{3}\end{array}$ & $\begin{array}{c}0.27 \times 0.27 \mathrm{~m} \\
0.729 \mathrm{~m}^{3}\end{array}$ \\
\hline$[\mathrm{m}]$ & {$[\mathbf{m} / \mathbf{s}]$} & \multicolumn{5}{|c|}{ Amount of exhaust air streams $\left[\mathrm{m}^{3} / \mathrm{h}\right]$} \\
\hline 1 & 2 & 3 & 4 & 5 & 6 & 7 \\
\hline 1 & 0.21 & 14.82 & 21.17 & 28.58 & 30.24 & 55.08 \\
\hline 2 & 0.36 & 25.38 & 36.29 & 48.99 & 51.84 & 94.46 \\
\hline 3 & 0.48 & 33.87 & 48.38 & 65.32 & 69.12 & 125.99 \\
\hline 4 & 0.60 & 42.34 & 60.48 & 81.65 & 86.40 & 157.46 \\
\hline 5 & 0.68 & 47.98 & 68.54 & 92.53 & 97.92 & 178.46 \\
\hline 6 & 0.77 & 54.33 & 77.62 & 104.78 & 110.88 & 202.08 \\
\hline 7 & 0.83 & 58.56 & 83.66 & 112.95 & 119.52 & 217.83 \\
\hline 8 & 0.88 & 62.04 & 88.70 & 119.75 & 126.72 & 230.95 \\
\hline 9 & 0.93 & 65.62 & 93.74 & 126.55 & 133.92 & 244.07 \\
\hline 10 & 0.99 & 69.75 & 99.78 & 133.36 & 141.12 & 257.19 \\
\hline 11 & 1.03 & 72.68 & 103.82 & 140.16 & 148.32 & 270.31 \\
\hline
\end{tabular}

Assuming standard cross-sectional area of a duct without making calculations, it is very easy to make a mistake, which will lead to insufficient ventilation in the rooms.

It is important to remember that gas stoves belong to devices that take its combustion air out of the room being installed or through the inlet grille (air intake) from outside the building. In the case when a gas stove is installed in the room, the inflow of fresh air takes on a special significance. The necessary amount of fresh air must be supplied for the fuel combustion process.

How important this task is, we can prove by calculating the amount of air that should be delivered to the cooker, which has average nominal power of $11 \mathrm{~kW}$.

High-methane natural gas (E) consists in $97-98 \%$ of methane $\left(\mathrm{CH}_{4}\right)$. Other compounds, which are present in the natural gas in small amounts, for example propane, butane, carbon dioxide are of minor importance and to simplify they will be omitted from our considerations. It requires a simple stoichiometric calculation to discover that for the combustion of $1 \mathrm{~m}^{3}$ of gas [9], the required amount of fresh air is $9.52 \mathrm{~m}^{3}$. 
Assuming that the amount of air that must be delivered to the device must be increased by $15 \%$, (the excess-air ratio $\lambda=1.15$ ), the actual volume of air delivered to burn $1 \mathrm{~m}^{3}$ methane is equal:

$$
\mathrm{V}=9.52 \times 1.15=10.95 \mathrm{~m}^{3}
$$

Assuming that the average calorific power of the gas is $10.35 \mathrm{kWh} / \mathrm{m}^{3}$, and the efficiency of the burner amounts to $60-65 \%$, can be determined the amount of gas, which has to be delivered to the gas cooker within one hour

$$
\mathrm{Q}=10.8 /(10.35 \times 0.65)=1.61 \mathrm{~m}^{3} / \mathrm{h}
$$

The quantity of air consumed by a cooker is equal:

$$
\mathrm{q}=1.61 \times 10.95=17.62 \mathrm{~m}^{3} / \mathrm{h}
$$

This is the required amount of fresh air, which has to be delivered in one hour to the gas stove in the kitchen room to enable it to function properly. This amount of air must be additionally supplied, regardless of the air necessary for hygienic and sanitary purposes.

If, during combustion the natural gas, the amount of air supplied is lower than required, carbon monoxide will appear in the combustion products next to carbon dioxide. The smaller the amount of oxygen will be available during the combustion reaction, the more carbon monoxide will be.

However, poor ventilation will also contribute to pollute the air in the kitchen by nitrogen oxides, which are inevitably created by using the cookers.

In the case of properly operating gravity ventilation, the volume flow rates of the extract air and infiltrating air should be equal. This is usually done through leaks in the window and door openings and airing, rarely through air inlets.

In the winter period (heating season), the dangerous concentration of harmful substances in the living space increases significantly due to avoid heat loss caused by airing rooms. As a consequence, often residential rooms are practically devoid of ventilation, and through the tight window and door woodwork, the outside air necessary for the proper operation of the devices is not entered in the appropriate quantities.

According to the standard [6], in buildings up to the 9 floor above ground, it is allowed to supply air through windows, which are characterized by infiltration coefficient "a" higher than 0.5 , but not more than $1.0 \mathrm{~m}^{3} /\left(\mathrm{m} \times \mathrm{h} \times \mathrm{daPa}^{2 / 3}\right)$.

For a standard kitchen with an outside window and a gas stove, the minimum total extract air stream $\mathrm{Vw}$ should be equal $90 \mathrm{~m}^{3} / \mathrm{h}\left(70 \mathrm{~m}^{3} / \mathrm{h}\right.$ - for hygiene and sanitary purposes, $20 \mathrm{~m}^{3} / \mathrm{h}$ - air necessary for combustion).

The same amount of fresh air has to be delivered to the kitchen from outside. A negative pressure of $10 \mathrm{~Pa}(1 \mathrm{daPa})$ is required to achieve the volume of required air flow through the infiltration. Then, for the window with the maximum infiltration coefficient of $1.0 \mathrm{~m}^{3} /\left(\mathrm{m} \times \mathrm{h} \times \mathrm{daPa}^{2 / 3}\right)$, through $1 \mathrm{~m}$ of the gap (regardless of its width), the airflow of $1.0 \mathrm{~m}^{3} /(\mathrm{m} \times \mathrm{h})$ will flow. The minimum length of the gaps will be:

$$
\mathrm{Lg}=\mathrm{Vw} / \mathrm{Vo}=90 / 1.0=90 \mathrm{~m}
$$

In order to create the required negative pressure in the kitchen, assuming that it will be the result of only the active negative pressure caused by gravity ventilation in reference design conditions, the required channel height should be:

$$
\mathrm{H}_{\mathrm{ch}}=\mathrm{P}_{\mathrm{a}} /(\mathrm{g} \times(\rho \mathrm{e}-\rho \mathrm{i}))=10 /(9.81 \times(1.238-1.204))=29.98 \mathrm{~m}
$$


This would mean that the proper level of infiltration would be ensured only for a channel with a height of ca. $30 \mathrm{~m}$ and with a length of infiltration gaps of $90 \mathrm{~m}$. It is practically impossible to implement. Air infiltration only by leakage area in window and door woodworks does not fulfill its task.

\section{Theoretical calculations of NOx concentration generated in the air of gasified kitchen}

In Poland, the regulations specify that during the annual inspection of the gas installation, must be checked its tightness measured by the detector and except that a measurement of carbon monoxide in the flue gas should be made. This measurement shall be carried out in a stream not more than $10 \mathrm{~mm}$ above the burners of the gas cooker and the oven.

The regulations do not indicate the necessity to carry out tests on the concentration of nitrogen oxides.

In Russia, environmental requirements for household gas cookers have been introduced since 1985 - according to the threshold levels of concentration of nitrogen oxides, which should not exceed $200 \mathrm{mg} / \mathrm{m}^{3}$ [10] in the flue gases.

Although it is difficult to separate the process of flue gas formation from the process of their continuous mixing with the surrounding air due to gas burners affect the space of the entire apartment, the Russian standard gives the opportunity to estimate this possible concentration of NOx in the air of the gasified kitchen.

The flow of gas characterized by a calorific value of $37.60 \mathrm{MJ} / \mathrm{m}^{3}$ with both burners (with a nominal power of $2.00 \mathrm{~kW}$ and $2.90 \mathrm{~kW}$ ) operating simultaneously will be:

$$
(2.00+2.9) \times 10^{-3} / 37.60 \times 3600=0.469 \mathrm{~m}^{3} / \mathrm{h}
$$

The expected flue gas stream entering rooms (at the theoretical unit volume of dry basis combustion products, which is $8.52 \mathrm{~m}^{3} / \mathrm{m}^{3}$ ) [9], and taking into account that the standard $200 \mathrm{mg} / \mathrm{m} 3$ is converted into $\alpha=1$, will amount to:

$$
0.469 \times 8.52=3.996 \mathrm{~m}^{3} / \mathrm{h}
$$

In this way, the amount of nitrogen oxides going into the rooms of the kitchen can be equal:

$$
3.996 \times 200=799.2 \mathrm{mg} / \mathrm{h}
$$

On the assumption that the calculation stream of air exchange for a kitchen room with a window equipped with a gas stove should not be less than $90 \mathrm{~m}^{3} / \mathrm{h}$, the possible concentration of NOx directly in the kitchen room will be:

$$
799.2 / 90=8.88 \mathrm{mg} / \mathrm{m}^{3}
$$

As mentioned before, there are no standards specifying the permissible concentration of nitrogen oxides for living spaces, comparison can only be made for air in the working zone.

It is easy to notice that the obtained result significantly exceeds the long-term permissible concentration for the working zone, which is $3.5 \mathrm{mg} / \mathrm{m}^{3}$.

Although the time spent by people in the kitchen room is usually less than 8 hours per day (employee exposure time, provided for by the above regulation), there is a strong possibility of high concentrations of NOx and other compounds, including $\mathrm{CO}$ (with a higher load of the oven or degraded ventilation in kitchen rooms) occurring. 


\section{Experimental research}

The measurements were taken in a kitchen room, located on the second floor of a fivestorey multi-family building.

It was a standard kitchen with a ventilation duct built in brick technology with a crosssection of 140x140 mm and installed top hung window with dimensions of $172 \times 142 \mathrm{~cm}$. The kitchen was equipped with a gas stove with a gas oven, with the following nozzles parameters:

$\begin{array}{ll}\text { Nozzle no. 1 } & 1000 \mathrm{~W} \\ \text { Nozzle no. 2 } & 2900 \mathrm{~W} \\ \text { Nozzle no. 3,4 } & 2000 \mathrm{~W} \\ \text { Oven } & 2900 \mathrm{~W}\end{array}$

Despite the fact that researches of concentrations of nitrogen oxides and carbon monoxide have normalized Standard Test Method for Measuring, however, for the analysis of chemical pollution arising in the kitchen, for the needs of the experiment, the exhaust gas analyzer giving the measurement result in real time was used.

The measurements were carried out using a legalized "SIGMA" exhaust gas analyzer, meeting the requirements of the PN-EN 482:2002 standard.

The procedure commonly known for the test of exhaust emissions in boiler furnaces was used, where the substances are supplied to the volume of the tested object. Then, they react with each other and the products of reaction are continuously discharged.

In the examined case, the amount of gas burned, the amount of harmful substances emitted from the stove burners, as well as the stream of air supplied and removed from the kitchen were remained at a constant level. The test were started were started after 30 minutes of stove operation, assuming that during this time, the work of the burners and the air movement in the room were stabilized.

Under the above it is reasonable to assume, that the measurement conditions were stationary and the concentrations of the substances in the air were unchanged over time.

Localization of measuring points was made on a rectangular grid, to which the kitchen room was divided. They were located in the grid nodes, and $10.0 \mathrm{~cm}$ intervals were taken between the nodes. In order to determine the credible impact of the gas cooker, the measurements were made in increments of $5 \mathrm{~cm}$ in the height range from 1.50 to $2.00 \mathrm{~m}$ to include the breathing zone of an adult human. The results obtained are summarized in Table 4 and are shown schematically in Figure 1.

Table 4. Summary of NOx concentration measurements in the tested room.

\begin{tabular}{|c|c|c|c|c|c|c|}
\hline \multirow[t]{2}{*}{ ON. } & \multirow[t]{2}{*}{ The way of conducting the experiment } & \multicolumn{5}{|c|}{$\begin{array}{l}\text { Concentration of } \mathrm{NOx} \\
\text { (converted in } \mathrm{NO}_{2} \text { ) } \mathrm{w} \mathrm{mg} / \mathrm{m}^{3} \\
\text { as an isoline diagram }\end{array}$} \\
\hline & & 0 & $\bullet$ & $x$ & $\Delta$ & $\Delta$ \\
\hline 1. & $\begin{array}{l}\text { There were switched on: four cooker burners are on } \\
(7.9 \mathrm{~kW}) \text { or two largest burners and an oven burner } \\
(7.8 \mathrm{~kW}) \text {. Window, door to the next room - opened. }\end{array}$ & 20 & 10 & 5 & 3 & 1 \\
\hline 2. & $\begin{array}{l}\text { There were switched on both middle burners } \\
(4.00 \mathrm{~kW}) \text { or the smallest burner and oven burner } \\
(3.9 \mathrm{~kW}) \text {. Window, door to the next room - opened. }\end{array}$ & 13 & 6 & 4 & 2 & $<1$ \\
\hline 3. & $\begin{array}{l}\text { There were switched on both middle burners } \\
(4.00 \mathrm{~kW}) \text { or the smallest burner and oven burner } \\
(3.9 \mathrm{~kW}) \text {. Window, door to the next room - closed }\end{array}$ & 18 & 9 & 5 & 4 & 1 \\
\hline
\end{tabular}




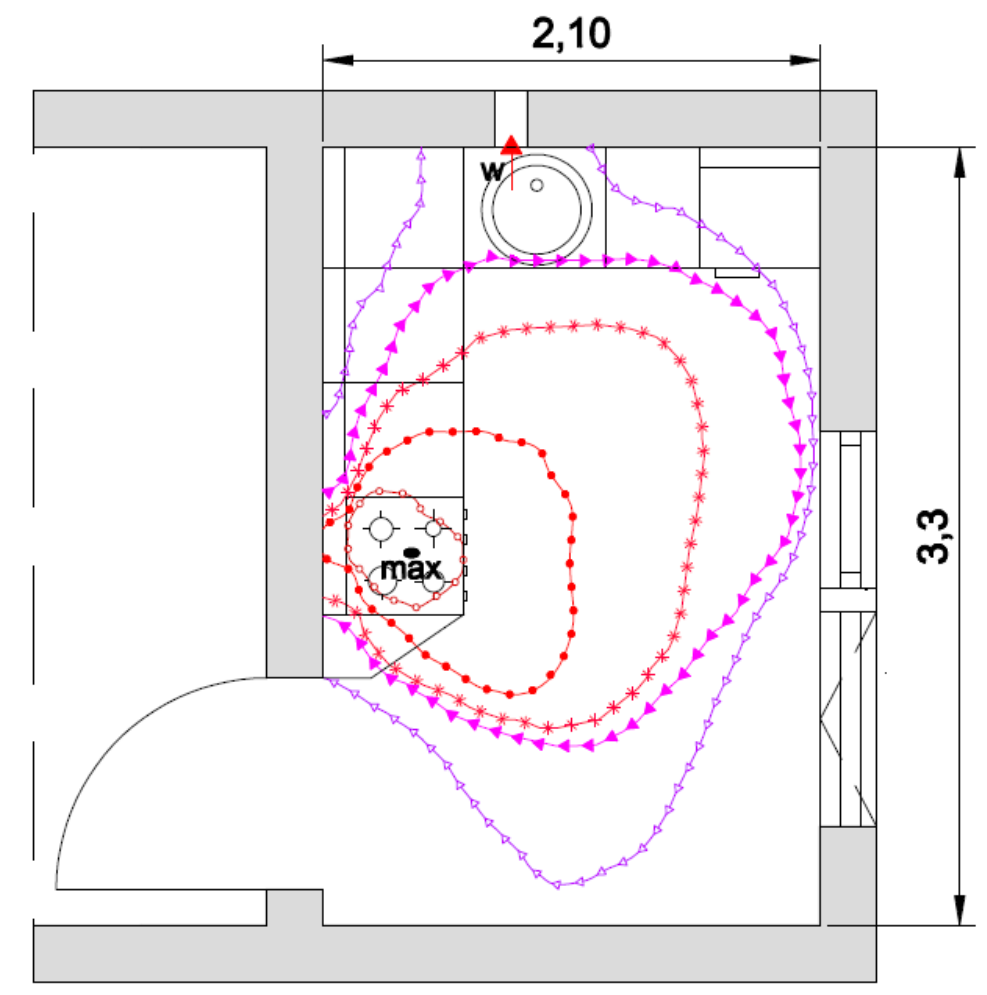

Fig 1. Isolines the concentration of nitric oxide in the kitchen room.

Survey evidence shows that with very average operating conditions of the gas cooker in a large part of the kitchen room (at a height of 1.5-2.0 $\mathrm{m}$ above floor level), concentration of NOx exceeds the permissible, long-term concentration of the working zone (up to $20 \mathrm{mg} / \mathrm{m}^{3}$ ). At the same time, the entire room has a concentration of CO up to $5 \mathrm{mg} / \mathrm{m}^{3}$.

The great social campaign in the media has made the public more increasingly aware of the imminent dangers arising from the using residential gas boilers. However, people usually don't realize that gas stoves can also be dangerous.

It turns out that where we should feel safe, there is a real threat to our health and safety.

\section{Conclusions}

- Gravitational ventilation system is often ineffective. Cross sections of gravity channels are usually assumed as typical, without taking into account their height and location in the apartment.

- The amount of external air necessary for the proper operation of the gas cooker, entered only by leakage area in window and door woodworks is insufficient.

- Theoretical calculations indicate that during the operation of the gas cooker, very high concentrations of NOx may occur in the kitchen.

- Preliminary experimental studies confirm that the NOx concentration can significantly exceed the acceptable standards for work zones. 


\section{References}

1. Zarządzenie Ministra Zdrowia i Opieki Społecznej z dnia 12 marca 1996 r. w sprawie dopuszczalnych stężeń i natężeń czynników szkodliwych dla zdrowia, wydzielanych przez materiały budowlane, urządzenia i elementy wyposażenia $\mathrm{w}$ pomieszczeniach przeznaczonych na pobyt ludzi.

2. R. Miller, Ochr Sr. 1, 64, 33-37 (1997)

3. M. Bieniek, Research Reports. Mining and Environment 2, 2-17 (2008)

4. J.M. Logue, N.E. Klepeis, A.B. Lobscheid, B.C. Singer, EHP 22, 43-50 (2014)

5. Rozporządzenie Ministra Pracy i Polityki społecznej z dnia 6 czerwca 2014 r. w sprawie najwyższych dopuszczalnych stężeń i natężeń czynników szkodliwych dla zdrowia w środowisku pracy.

6. U. Duda, M. Kłys, F. Trela, Arch. Med. Sąd. Krym XLVII (1997)

7. PN-83/B-03430+A3:2000 Wentylacja w budynkach mieszkalnych, zamieszkania zbiorowego i użyteczności publicznej. Wymagania. Norma wycofana. Niezastąpiona

8. S. Opaliński, S. Rabczak Wentylacja grawitacyjna (Oficyna Wydawnicza Politechniki Rzeszowskiej, 2003)

9. A. Szkarowski. Spalanie gazów. Teoria, praktyka, ekologia (Wydawnictwo WNT 35, 2014)

10. Norma rosyjska ГОСТ 10798-85 Плиты газовые бытовые. Общие технические условия / ГОСТ Р 50696-94 / ГОСТ Р 50696-2006 